\title{
Characterization of a Novel Endophytic Actinomycete, Streptomyces physcomitrii sp. nov., and Its Biocontrol Potential Against Ralstonia solanacearum on Tomato
}

\author{
Xiaoxin Zhuang ${ }^{1, \dagger}$, Congting Gao ${ }^{1,+}$, Chenghui Peng ${ }^{1}$, Zhiyan Wang ${ }^{2}$, Junwei Zhao ${ }^{1}$, \\ Yue Shen ${ }^{1, *}$ and Chongxi Liu ${ }^{1,2, *}$ \\ 1 Key Laboratory of Agricultural Microbiology of Heilongjiang Province, Northeast Agricultural University, \\ Harbin 150030, China; zxx221661@163.com (X.Z.); g2456692645@163.com (C.G.); ppoapeng@163.com (C.P.); \\ zhaojunwei@neau.edu.cn (J.Z.) \\ 2 State Key Laboratory of Phytochemistry and Plant Resources in West China, Kunming Institute of Botany, \\ Chinese Academy of Sciences, Kunming 650201, China; zhiyan_w@163.com \\ * Correspondence: shenyue@neau.edu.cn (Y.S.); liuchongxi@neau.edu.cn (C.L.) \\ + These authors have contributed equally to this work.
}

Received: 13 November 2020; Accepted: 15 December 2020; Published: 18 December 2020

check for updates

\begin{abstract}
Bacterial wilt of tomato is a destructive disease caused by Ralstonia solanacearum throughout

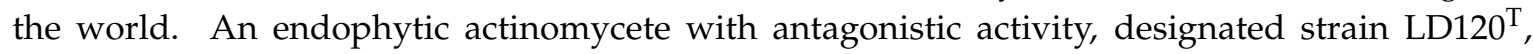
was isolated from moss (Physcomitrium sphaericum (Ludw) Fuernr). The biocontrol test demonstrated that co-inoculation by the isolate and the pathogen gave the greatest biocontrol efficiency of $63.6 \%$. Strain $\mathrm{LD} 120^{\mathrm{T}}$ had morphological characteristics and chemotaxonomic properties identical to those of members of the genus Streptomyces. The diamino acid present in the cell wall was LL-diaminopimelic acid. Arabinose, glucose, rhamnose, and ribose occured in whole cell hydrolysates. The menaquinones detected were MK-9 $\left(\mathrm{H}_{4}\right)$, MK-9 $\left(\mathrm{H}_{6}\right)$, MK-9 $\left(\mathrm{H}_{8}\right)$, and MK-9 $\left(\mathrm{H}_{2}\right)$. The polar lipid profile was found to contain diphosphatidylglycerol, phosphatidylethanolamine, and phosphatidylinositol. The major cellular fatty acids were found to be iso- $C_{16: 0}$, iso- $C_{17: 0}$, anteiso- $C_{15: 0}$, and $C_{16: 1} \omega 7 \mathrm{c}$. The DNA $\mathrm{G}+\mathrm{C}$ content of the draft genome sequence, consisting of $7.6 \mathrm{Mbp}$, was $73.1 \%$. Analysis of the $16 \mathrm{~S}$ rRNA gene sequence showed that strain LD120 ${ }^{\mathrm{T}}$ belongs to the genus Streptomyces, with the highest sequence similarity to Streptomyces azureus NRRL B-2655 ${ }^{\mathrm{T}}(98.97 \%)$, but phylogenetically clustered with Streptomyces anandii NRRL B-3590 ${ }^{\mathrm{T}}$ (98.62\%). Multilocus sequence analysis based on five other house-keeping genes $(a t p D, g y r B, r p o B, r e c A$, and $\operatorname{trp} B)$ and the low level of DNA-DNA relatedness, as well as phenotypic differences, allowed strain $\mathrm{LD} 120^{\mathrm{T}}$ to be differentiated from its closely related strains. Therefore, the strain was concluded to represent a novel species of the genus Streptomyces, for which the name Streptomyces physcomitrii sp. nov. was proposed. The type strain was LD120 $\left(=\right.$ CCTCC AA $\left.2018049^{\mathrm{T}}=\mathrm{DSM} 110638^{\mathrm{T}}\right)$.
\end{abstract}

Keywords: Ralstonia solanacearum; antagonistic activity; biocontrol; Streptomyces physcomitrii sp. nov.; moss

\section{Introduction}

$R$. solanacearum, a soil-borne phytopathogen that causes vascular wilt disease, is considered the second most destructive plant pathogenic bacteria [1]. The bacterial wilt disease was first observed in southern potato tubers in the United States [2]. In 1896, its causal agent was described [3]. The pathogen can infect more than 450 plant species belonging to 54 families and is particularly devastating to tomato, leading to huge agricultural losses in tropical, subtropical, and warm-temperature regions 
of the world $[4,5]$. Up till now, no effective chemical management strategy for this disease has been available [6]. Therefore, new natural resources or antibiotics for controlling this disease are urgent.

The use of antagonistic bacteria as biocontrol agents is a promising approach for the management of soil borne pathogens. Some species have been commercialized for biological control, such as Bacillus subtilis (QST $\left.{ }^{\circledR}\right)$, Pseudomonas syringae (Bio-save ${ }^{\circledR}$ ), Metschnikowia fructicola (Shemer ${ }^{\circledR}$ ), and Streptomyces lydicus WYEC108 (Actinovate ${ }^{\circledR}$ ) [7]. Recently, some studies showed that biological control of bacterial wilt disease using antagonistic bacteria could be achieved [8-10]. Antagonistic bacteria is also proved to be effective in controlling bacterial wilt disease under field conditions [11].

Endophytic actinobacteria are those that inhabit various tissues or organs of healthy plants at specific growth stages or whole stages of their life cycle without harm to host plants [12]. Many members of this taxonomic group contribute to plant natural defenses through the production of antibiotics or induction of systemic disease resistance [13-15]. It has been also reported that several endophytic actinobacteria have the potential as biocontrol agents against economically important plant pathogens, such as Botryosphaeria dothidea [16], Fusarium oxysporum [15], and Sclerotinia sclerotiorum [17]. Hence, we have reason to believe that endophytic actinobacteria are resources for controlling bacterial wilt disease.

During our search for endophytic actinobacteria with biocontrol potential against $R$. solanacearum, an antagonistic actinobacteria, strain LD120 ${ }^{\mathrm{T}}$, was isolated from moss (P. sphaericum (Ludw) Fuernr). In this study, we performed a polyphasic taxonomic analysis on this strain and proposed that strain $\mathrm{LD} 120^{\mathrm{T}}$ represents a new species of the genus Streptomyces. The in vivo bioassays demonstrated that the strain had good biocontrol potential against bacterial wilt disease on tomato.

\section{Materials and Methods}

\subsection{Strains}

Strain LD $120^{\mathrm{T}}$ was isolated from moss (P. sphaericum (Ludw) Fuernr) collected in Kunming, Yunnan Province, southwest China $\left(25^{\circ} 21^{\prime} \mathrm{N}, 102^{\circ} 92^{\prime} \mathrm{E}\right)$. The moss sample was air-dried for $24 \mathrm{~h}$ at room temperature and then washed in sterile distilled water with an ultrasonic step (160 W, $15 \mathrm{~min})$ to remove the surface soil completely. After drying, the sample was subjected to a seven-step surface sterilization procedure, as described by Liu et al. [14]. After being thoroughly dried under sterile conditions, the sample was ground with a mortar and pestle, employing $1 \mathrm{~mL}$ of $0.5 \mathrm{M}$ potassium phosphate buffer (pH 7.0) per $100 \mathrm{mg}$ tissue. Tissue particles were allowed to settle down at $4{ }^{\circ} \mathrm{C}$ for 20-30 min, and the supernatant was spread on cellulose-proline agar (CPA) [18] supplemented with cycloheximide $(50 \mathrm{mg} / \mathrm{L})$ and nalidixic acid $(20 \mathrm{mg} / \mathrm{L})$. After 28 days of aerobic incubation at $28^{\circ} \mathrm{C}$, the single colony was transferred and purified on oatmeal agar (International Streptomyces Project (ISP) medium 3) [19] and maintained as glycerol suspensions $(20 \%, v / v)$ at $-80^{\circ} \mathrm{C}$. The reference strains, Streptomyces azureus NRRL B-2655 ${ }^{\mathrm{T}}$ and Streptomyces anandii NRRL B-3590 ${ }^{\mathrm{T}}$, were purchased from China General Microbiological Culture Collection Center (CGMCC) for comparative analysis.

\subsection{Phenotypic Characterization}

Spore morphology was observed using scanning electron microscopy (Hitachi SU8010, Hitachi Co., Tokyo, Japan) after cultivation on ISP3 medium at $28^{\circ} \mathrm{C}$ for 28 days. Samples for scanning electron microscopy were prepared, as described by Jin et al. [20]. Cultural characteristics were determined after 14 days at $28^{\circ} \mathrm{C}$ using ISP media 1-7 [19], modified Bennett's agar (MBA) [21], nutrient agar (NA) [22], and Czapek's agar (CA) [22]. Growth at different temperatures $(4,10,15,20,28,35,37$, 40 , and $45^{\circ} \mathrm{C}$ ) was determined on ISP3 medium after incubation for 14 days. Tolerance of $\mathrm{pH}$ range ( $\mathrm{pH} 4-12$, at intervals of $1 \mathrm{pH}$ units), using a buffer system, was described by Zhao et al. [23], and $\mathrm{NaCl}$ tolerance $(0-12 \%$, with an interval of $1 \%, w / v)$ for growth was determined after 3 days of growth in TSB broth [24] in shake flasks $(250 \mathrm{rpm})$ at $28^{\circ} \mathrm{C}$. The utilization of sole carbon and nitrogen sources was 
carried out, as described previously [25]. Other physiological and biochemical characteristics were conducted, according to a previous report [26].

\subsection{Chemotaxonomic Characterization}

Biomass for chemical studies was prepared by growing strain $\mathrm{LD} 120^{\mathrm{T}}$ in GY broth [27] in shake flasks at $28^{\circ} \mathrm{C}$ for 3 days. The isomers of diaminopimelic acid (DAP) in the cell wall hydrolysates were derivatized according to the method of McKerrow et al. [28] and analyzed by HPLC using an Agilent TC-C18 Column $(250 \times 4.6 \mathrm{~mm}$ i.d. $5 \mu \mathrm{m})$ [26]. The whole-cell sugars were analyzed by thin-layer chromatography (TLC, Qingdao Marine Chemical Inc., Qingdao, China) [29]. Phospholipids in cells were examined by two-dimensional TLC and identified according to the procedures developed by Minnikin et al. [30]. Menaquinones were extracted from freeze-dried biomass and purified using the method of Collins [31]. The extracts were analyzed by a HPLC-UV method, as described previously [26]. Fatty acids were prepared and analyzed by GC-MS according to the method of Zhuang et al. [32].

\subsection{Phylogenetic Analysis}

Strain LD120 ${ }^{\mathrm{T}}$ was cultured in GY broth for 3 days at $28^{\circ} \mathrm{C}$ to harvest cells. The genomic DNA was isolated using a Bacteria DNA Kit (TIANGEN Biotech, Co. Ltd., Beijing, China). The primers and procedure for PCR amplification were performed as described by Wang et al. [33]. The purified PCR product was cloned into the vector pMD19-T (Takara, Shiga, Japan) and sequenced by using an Applied Biosystems DNA sequencer (model 3730XL, Applied Biosystems Inc., Foster City, CA, USA). The almost complete $16 \mathrm{~S}$ rRNA gene sequence (1522 bp) was uploaded to the EzBioCloud server (Available online: https://www.ezbiocloud.net/) [34] to calculate pairwise 16S rRNA gene sequence similarity between strain $\mathrm{LD} 120^{\mathrm{T}}$ and related similar species. Phylogenetic trees were constructed using the neighbor-joining [35] and maximum likelihood [36] algorithms using MEGA 7.0 software [37]. The confidence values of branches were assessed using bootstrap resampling with 1000 replication [38]. A distance matrix was calculated using Kimura's two-parameter model [39]. All positions containing gaps and missing data were eliminated from the dataset (complete deletion option). Phylogenetic relationships of strain $\mathrm{LD} 120^{\mathrm{T}}$ were also confirmed using sequences for five concatenated housekeeping genes $(r e c A, g y r B, a t p D, r p o B$, and $\operatorname{trp} B)$. The sequences of $L D 120^{\mathrm{T}}$ were obtained from the whole genome. The sequences of each locus were aligned using MEGA 7.0 software and trimmed manually at the same position before being used for further analysis. Phylogenetic analysis was performed as described above.

\subsection{Genome Analysis}

Genomic DNA was extracted using the lysozyme-sodium dodecyl sulfate-phenol/chloroform method [40]. The whole genome was sequenced on the HiSeq 2500 Sequencing System (Illumina, San Diego, CA, USA), according to the user guide, and assembled on MiSeq plateform [41]. The digital DNA-DNA hybridization ( $\mathrm{dDDH}$ ) and average nucleotide identity (ANI) values were determined between the draft genome sequences of strain $\mathrm{LD} 120^{\mathrm{T}}$ and S. azureus NRRL B- $2655^{\mathrm{T}}$ and S. anandii NRRL B-3590 ${ }^{\mathrm{T}}$ online at http://ggdc.dsmz.de using the Genome-to-Genome Distance Calculation (GGDC 2.0) [42] and the ChunLab's online ANI Calculator (www.ezbiocloud.net/tools/ani) [43], respectively. Genome mining analysis was performed with antiSMASH (version 4.0, Blin K, Oxford, UK) [44].

\subsection{Activity Evaluation of Strain $L D 120^{T}$ against R. solanacearum In Vitro}

The phytopathogenic $R$. solanacearum strain FJAT-91 used in this study was kindly provided by Fujian Academy of Agricultural Sciences. R. solanacearum was cultured in sucrose-peptone (SP) broth (sucrose $2 \%$, peptone $0.5 \%, \mathrm{KH}_{2} \mathrm{PO}_{4} 0.05 \%, \mathrm{MgSO}_{4} \cdot 7 \mathrm{H}_{2} \mathrm{O} 0.025 \%$, $\mathrm{pH} 7.0$ ) for $12 \mathrm{~h}$ at $37^{\circ} \mathrm{C}$. Then, $100 \mu \mathrm{L}$ of bacterial suspension $\left(10^{8} \mathrm{CFU} / \mathrm{mL}\right)$ was plated onto sucrose-peptone agar (SPA) media. A fresh mycelial agar plug ( $5 \mathrm{~mm}$ diameter) of strain $\mathrm{LD} 120^{\mathrm{T}}$, which was cut from the margin of the 
mycelium grown on the ISP3 medium, was placed in the center of the SPA plate and incubated at $37^{\circ} \mathrm{C}$. The diameter of the inhibition zone was measured after $12 \mathrm{~h}$. Experiments were performed in triplicate.

\subsection{The Biocontrol Efficacy of Strain $L D 120^{T}$ against R. solanacearum}

The preventive experiment was performed in this study to evaluate the biocontrol efficacy of strain $\mathrm{LD} 120^{\mathrm{T}}$ against $R$. solanacearum on tomato under greenhouse conditions. The spore suspension of strain LD120 $0^{\mathrm{T}}$ was irrigated in the soil at concentrations of $10^{5} \mathrm{CFU} / \mathrm{g}, 10^{6} \mathrm{CFU} / \mathrm{g}, 10^{7} \mathrm{CFU} / \mathrm{g}$, and $10^{8} \mathrm{CFU} / \mathrm{g}$ soil, respectively. Tomato seedlings (Maofen 802) were purchased from Shouguang AOLIDE Agricultural Technology Co., Ltd. (Shouguang, China). When plants grew at the four-leaf stage, tomato seedlings were transferred into the pots (one tomato seedling per pot) that contained various concentrations of spores of strain $\mathrm{LD} 120^{\mathrm{T}}$. After growing for a week, $10 \mathrm{~mL}$ of cell suspension of $R$. solanacearum $\left(10^{8} \mathrm{CFU} / \mathrm{mL}\right)$ was poured into the soil around the plants. During the experiment, (1) no microbial suspension was added to the soil, "CK"; (2) both the spore suspension of strain LD120 and cell suspension of $R$. solanacearum were added to the soil; and (3) cell suspension of $R$. solanacearum were added to the soil "CKR". A total of 15 pots were used for each treatment, and the experiment was conducted three times, independently. The pots were kept at $30{ }^{\circ} \mathrm{C}$ and $70-80 \%$ humidity for 15 days. The disease severity was rated using the five class scale: (0), no symptoms; (1), one leaf partially wilted; (2), two or three leaves wilted; (3), all leaves wilted except the top two or three leaves; (4), all leaves wilted; (5), plant is dead [10]. The disease index (DI) was calculated using the formula: $(\Sigma$ (plant numbers with the same rating of disease severity $\times$ disease rating)/(maximum rating value $\times$ total number of plants)) $\times 100$. The biological control efficiency was calculated using the formula: ((DI of CKR - DI of the treatment)/ DI of CKR) $\times 100 \%$.

\section{Results and Discussion}

\subsection{Polyphasic Taxonomic Characterization of Strain LD120}

Identification using the EzTaxon-e server revealed that strain $\mathrm{LD} 120^{\mathrm{T}}$ belonged to the genus Streptomyces, with the highest $16 \mathrm{~S}$ rRNA gene sequence similarity to S. azureus NRRL B-2655 ${ }^{\mathrm{T}}$ (98.97\%). Additionally, $16 \mathrm{~S}$ rRNA gene sequence similarities between strain $\mathrm{LD} 120^{\mathrm{T}}$ and other species of the genus Streptomyces were lower than $98.7 \%$. A phylogenetic tree based on $16 \mathrm{~S}$ rRNA gene sequences showed that strain $\mathrm{LD} 120^{\mathrm{T}}$ formed a phyletic line with S. anandii NRRL B-3590 30 (98.62\%) in the neighbor-joining tree (Figure 1); a relationship also recovered in the maximum-likelihood tree (Figure S1). Further, phylogenetic analysis, based on the five housekeeping genes (Table S1) and whole-genome sequences, showed that strain $\mathrm{LD} 120^{\mathrm{T}}$ formed a separate clade (Figures 2, S2 and S3). Based on the phylogenetic trees and 16S rRNA gene similarities, the isolate was thought to be mostly related to $S$. azureus NRRL $\mathrm{B}-2655^{\mathrm{T}}$ and $S$. anandii NRRL B-3590 ${ }^{\mathrm{T}}$. dDDH indicated that DNA-DNA relatedness between strain LD120 ${ }^{\mathrm{T}}$ and S. azureus NRRL B-2655 ${ }^{\mathrm{T}}$ and S. anandii NRRL B-3590 ${ }^{\mathrm{T}}$ were $21.0-25.7 \%$ and $25.3-30.1 \%$, respectively, which are much lower than the cut-off point of $70 \%$ recommended for the assignment of bacteria strains to the same genomic species [45]. ANI values between LD120 ${ }^{\mathrm{T}}$ and the two type strains were $78.9 \%$ and $83.4 \%$, respectively, whose values were also below the recommended threshold for species delineation (95-96\%) [46]. In addition, The MLSA distances between the isolate and the two type strains were 0.108 and 0.118 , respectively (Table S2), which was well above the species level threshold of 0.007 , considered to be the threshold for species determination [47]. 


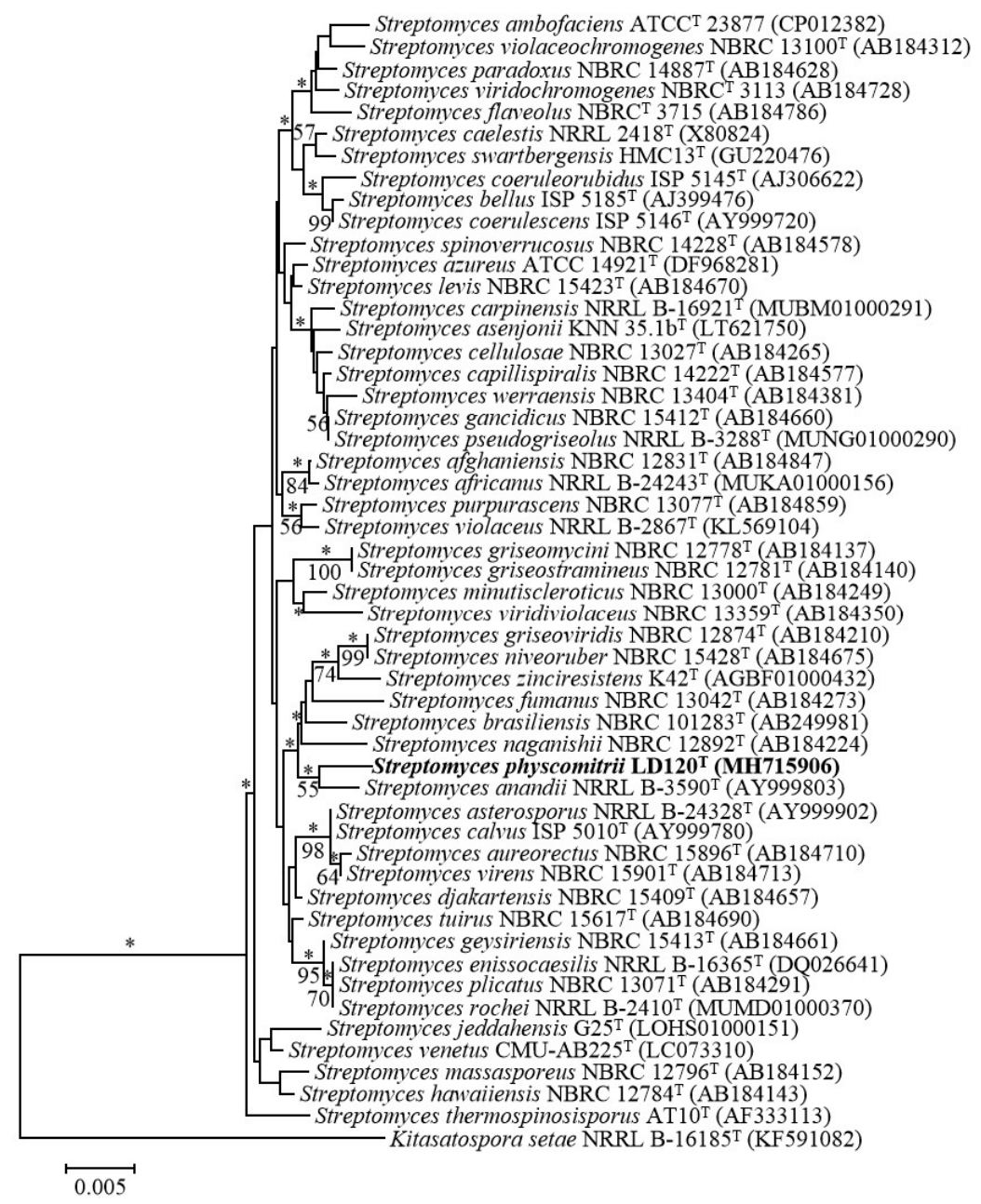

Figure 1. Neighbor-joining tree showing the phylogenetic position of strain $\mathrm{LD} 120^{\mathrm{T}}$ and related taxa based on 16S rRNA gene sequences. Asterisks $\left(^{*}\right)$ indicate branches that were also found using the maximum-likelihood method. Numbers at branch points indicate bootstrap percentages (based on 1000 replicates); only values $>50 \%$ are indicated. Bar, 0.005 substitutions per nucleotide position.

Morphological observation of a 2-week-old culture of strain LD120 $20^{\mathrm{T}}$ grown on ISP3 medium revealed showed that it had the typical characteristics of the genus Streptomyces [48]. Aerial and substrate mycelium were well developed without fragmentation. Long spore chains with warty surfaced spores $(0.5-0.6 \times 0.7-0.8 \mu \mathrm{m})$ were borne on the aerial mycelium (Figure 3$)$. Strain $\mathrm{LD} 120^{\mathrm{T}}$ grew well on ISP2, ISP3, ISP4, ISP6, ISP7, and MBA media but moderately on ISP1, ISP5, NA, and CA media. The colors of aerial mycelium were white, and those of the substrate mycelium varied from pale yellowish to light olive brown (Figure S4). Diffusible pigments were observed on ISP2, ISP4, ISP5, ISP7, NA, and MBA. The significant color variations of aerial and substrate mycelium and the production of diffusible pigments on different media are listed in Table S3, which shows morphological differences between strain $\mathrm{LD} 120^{\mathrm{T}}$ and the two closely related strains. Strain $\mathrm{LD} 120^{\mathrm{T}}$ could grow at a temperature range of $15-40{ }^{\circ} \mathrm{C}$, but not $45^{\circ} \mathrm{C}$, which can distinguish it from its closely related strains. Hydrolysis of starch and production of urease, as well as utilization of L-arginine and L-glutamic acid, could differentiate the isolate from S. azureus NRRL B- $2655^{\mathrm{T}}$. Meanwhile liquefaction of gelatin, coagulation of milk, and utilization of carbon sources could distinguish the isolate from S. anandii NRRL B-3590 ${ }^{\mathrm{T}}$. Other details of physiological and biochemical characteristics of strain LD120 ${ }^{\mathrm{T}}$ compared with its closely related strains are listed in Table 1. 


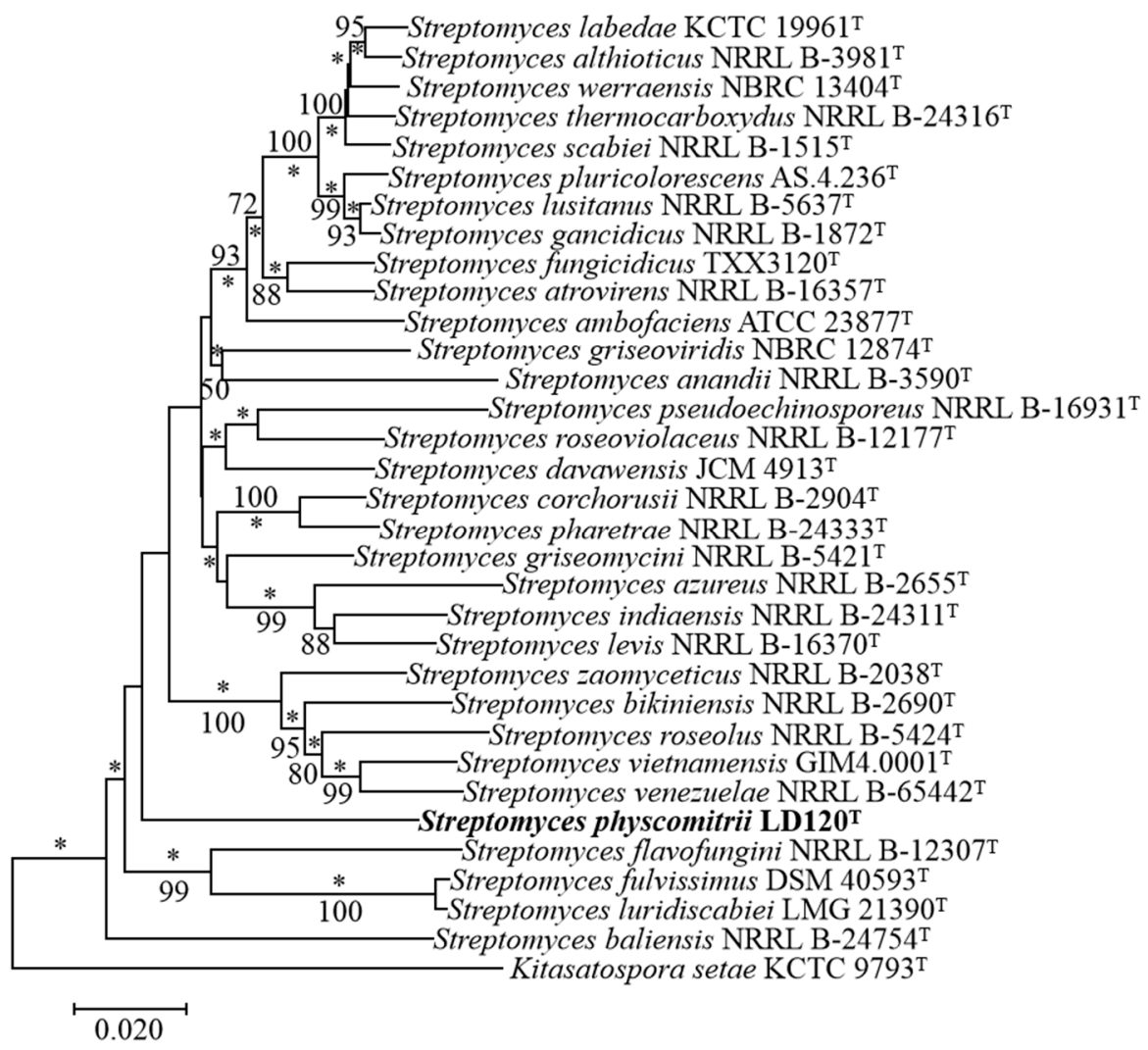

Figure 2. Neighbor-joining tree based on MLSA analysis of the concatenated partial sequences (2481 bp) from five housekeeping genes $\left(a t p D, g y r B, r e c A, r p o B\right.$, and $\operatorname{trp} B$ ) of strain $\mathrm{LD} 120^{\mathrm{T}}$ and related taxa. Only bootstrap values above $50 \%$ (percentages of 1000 replications) are indicated. Asterisks $\left(^{*}\right)$ indicate branches also recovered in the maximum-likelihood tree. Bar, 0.02 nucleotide substitutions per site.

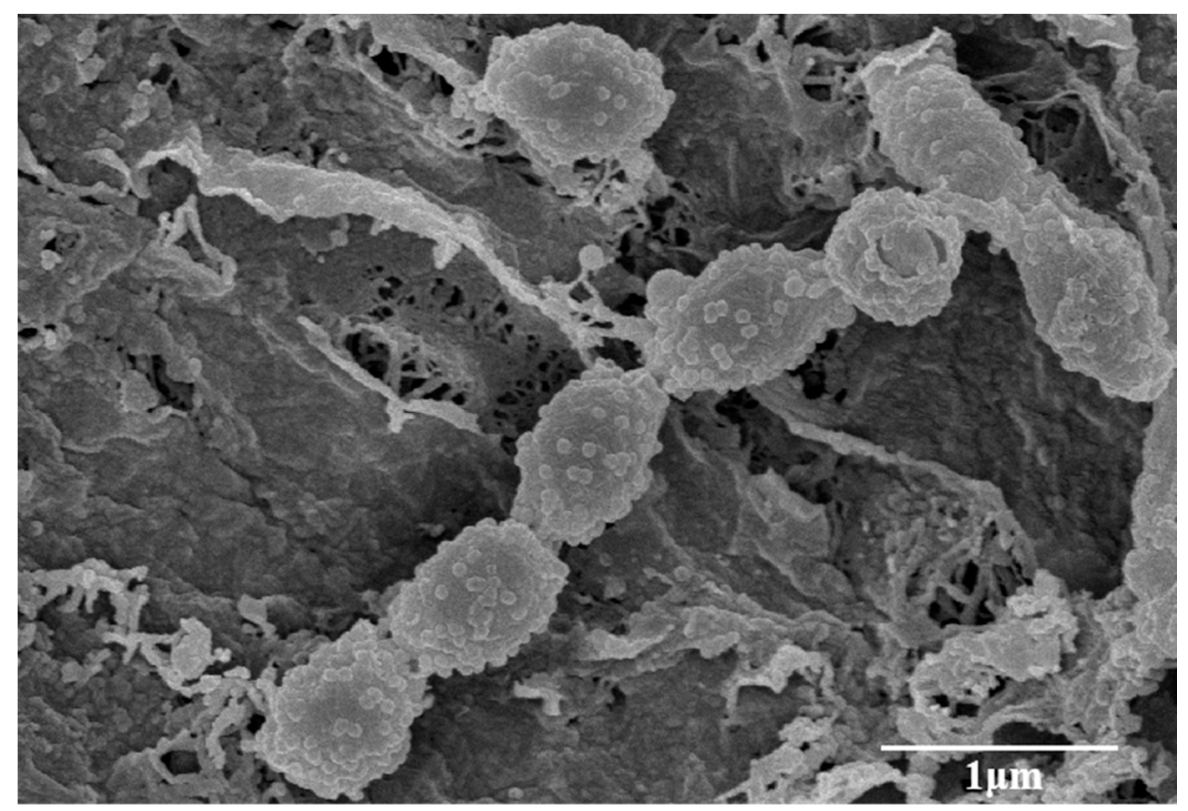

Figure 3. Scanning electron micrograph of strain $\mathrm{LD} 120^{\mathrm{T}}$ grown on International Streptomyces Project (ISP) medium 3 agar for 4 weeks at $28^{\circ} \mathrm{C}$. Bar $1 \mu \mathrm{m}$. 
Table 1. Differential characteristics of strain $\mathrm{LD} 120^{\mathrm{T}}$ and its closely related strains.

\begin{tabular}{cccc}
\hline Characteristic & $\mathbf{1}$ & $\mathbf{2}$ & $\mathbf{3}$ \\
\hline Growth at $45^{\circ} \mathrm{C}$ & - & + & + \\
$\mathrm{NaCl}$ tolerance range $(w / v, \%)$ & $0-8$ & $0-7$ & $0-10$ \\
Liquefaction of gelatin & - & - & + \\
Coagulation of milk & - & - & + \\
Hydrolysis of starch & + & - & + \\
Production of urease & - & + & - \\
Carbon source utilization & & & \\
L-arabinose & - & - & + \\
D-galactose & - & - & + \\
Meso-inositol & - & - & + \\
D-maltose & - & - & + \\
D-sorbitol & - & - & + \\
D-xylose & - & - & + \\
L-arginine & & & \\
L-glutamic acid & - & - & + \\
Nitrogen source utilization & - & + & - \\
\hline
\end{tabular}

Strains: 1, LD120 ; 2, S. azureus NRRL B-2655 ${ }^{\mathrm{T}}$; 3, S. anandii NRRL B-3590 ${ }^{\mathrm{T}}$. All data are from this study. +, positive; - , negative.

Chemotaxonomic analyses revealed that strain $\mathrm{LD} 120^{\mathrm{T}}$ exhibited characteristics that are typical of members of the genus Streptomyces [48]. It contained LL-diaminopimelic acid as the cell-wall diamino acid. The whole-cell sugars were arabinose, glucose, rhamnose, and ribose. The polar lipid profile consisted of diphosphatidylglycerol (DPG), phosphatidylethanolamine (PE), and phosphatidylinositol (PI) (Figure S5). The menaquinones detected were MK-9 $\left(\mathrm{H}_{4}\right)(42.3 \%)$, MK-9 $\left(\mathrm{H}_{6}\right)(34.3 \%)$, MK-9 $\left(\mathrm{H}_{8}\right)$ $(14.4 \%)$, and MK-9 $\left(\mathrm{H}_{2}\right)(9.0 \%)$. The major cellular fatty acids $(>10 \%)$ were iso- $\mathrm{C}_{16: 0}(22.9 \%)$, iso- $\mathrm{C}_{17: 0}$ $(16.9 \%)$, anteiso- $\mathrm{C}_{15: 0}(14.2 \%)$, and $\mathrm{C}_{16: 1} \omega 7 \mathrm{c}(12.7 \%)$ (Table 2). The fatty acid profile of strain LD120 ${ }^{\mathrm{T}}$ was evidently different from those of S. azureus NRRL B-2655 ${ }^{\mathrm{T}}$ and S. anandii NRRL B-3590 ${ }^{\mathrm{T}}$, such as the presence of $C_{14: 0}$ in $S$. anandii NRRL B- $3590^{\mathrm{T}}$ and a higher amount of anteiso- $\mathrm{C}_{17: 0}$ in $S$. azureus NRRL B-2655 ${ }^{\mathrm{T}}$, while there was a higher amount of iso- $\mathrm{C}_{17: 0}$ in strain LD120 ${ }^{\mathrm{T}}$.

Table 2. The cellular fatty acid compositions of strain $\mathrm{LD} 120^{\mathrm{T}}$ and its closely related strains.

\begin{tabular}{cccc}
\hline Fatty Acid & $\mathbf{1}$ & $\mathbf{2}$ & $\mathbf{3}$ \\
\hline Saturated fatty acids & & & \\
$\mathrm{C}_{14: 0}$ & - & - & 1.9 \\
$\mathrm{C}_{15: 0}$ & 1.0 & 1.8 & - \\
Unsaturated fatty acids & & & \\
$\mathrm{C}_{16: 1} \omega 7 \mathrm{c}$ & 12.7 & 12.8 & 13.3 \\
$\mathrm{C}_{17: 1} \omega 7 \mathrm{c}$ & 9.6 & 5.4 & 12.1 \\
Branched fatty acids & & & \\
$\mathrm{C}_{17: 0}$ cycle & 5.5 & 2.2 & 5.9 \\
iso-C $14: 0$ & 3.0 & 4.3 & 6.7 \\
iso-C $15: 0$ & 9.1 & 11.6 & 7.5 \\
anteiso-C & 15.2 & 13.2 & 13.9 \\
iso- $\mathrm{C}_{16: 0}$ & 22.9 & 20.1 & 21.6 \\
iso-C $17: 0$ & 16.9 & 8.5 & 9.1 \\
anteiso-C & & 19.3 & 7.9 \\
\hline
\end{tabular}

Strains: 1, LD120 7 ; , S. azureus NRRL B- $2655^{\mathrm{T}} ; 3$, S. anandii NRRL B- $3590^{\mathrm{T}}$. Values are percentages of total fatty acids. Fatty acids representing $<1 \%$ in all strains were omitted. All data are from this study. - , not detected. 
Therefore, it is evident from the genotypic and phenotypic data that strain $\mathrm{LD} 120^{\mathrm{T}}$ represents a novel species of the genus Streptomyces, for which the name S. physcomitrii sp. nov. is proposed.

\subsection{Description of S. physcomitrii sp. nov.}

S. physcomitrii (phys.co.mi'tri.i. N.L. gen. n physcomitrii of the moss Physcomitrium). Aerobic, Gram-stain-positive actinomycete that forms extensively-branched substrate mycelium and aerial hyphae. Linear spore chains are composed of non-motile spores with a warty surface. Growth occurs at $\mathrm{pH} 6-11$ (optimum $\mathrm{pH} 7$ ), at $15-40{ }^{\circ} \mathrm{C}$ (optimum $28^{\circ} \mathrm{C}$ ), and in the presence of $0-8 \%(w / v)$ $\mathrm{NaCl}$. It is positive for hydrolysis of starch, Tweens 40 and 80 , negative for hydrolysis of aesculin and Tweens 20, has a reduction of nitrate, liquefaction of gelatin, coagulation of milk, production of urease, decomposition of cellulose, and production of $\mathrm{H}_{2} \mathrm{~S}$. It utilizes D-fructose, D-glucose, lactose, D-mannitol, and D-ribose as sole carbon sources but not L-arabinose, D-galactose, meso-inositol, D-maltose, D-mannose, D-raffinose, L-rhamnose, D-sorbitol, D-sucrose, or D-xylose. It utilizes L-alanine, L-arginine, L-asparagine, L-aspartic acid, L-glutamine, glycine, L-serine, and L-threonine as sole nitrogen sources, but not creatine or L-glutamic acid. Cell walls contain LL-diaminopimelic acid as the diagnostic diamino acid, and the whole-cell sugars are arabinose, glucose, rhamnose, and ribose. The menaquinones detected are MK-9 $\left(\mathrm{H}_{4}\right)$, MK-9 $\left(\mathrm{H}_{6}\right)$, MK-9 $\left(\mathrm{H}_{8}\right)$, and MK-9 $\left(\mathrm{H}_{2}\right)$. The polar lipid profile consists of diphosphatidylglycerol (DPG), phosphatidylethanolamine (PE), and phosphatidylinositol (PI). The major cellular fatty acids are iso- $C_{16: 0}$, iso- $C_{17: 0}$, anteiso- $C_{15: 0}$, and $C_{16: 1} \omega 7 \mathrm{c}$

The type strain is $\operatorname{LD} 120^{\mathrm{T}}\left(=\mathrm{CCTCC}\right.$ AA $\left.2018049^{\mathrm{T}}=\mathrm{DSM} 110638^{\mathrm{T}}\right)$, isolated from moss $($ P. sphaericum (Ludw) Fuernr) collected in Kunming, Yunnan Province, southwest China. The DNA G + C content of the draft genome sequence of the type strain indicates a value of $73.1 \mathrm{~mol} \%$ for the species. The GenBank accession number for the $16 \mathrm{~S}$ rRNA gene sequence and the draft genome sequence of the type strain are MH715906 and JAAWWP000000000, respectively.

\subsection{Antibacterial Activity of Strain $L D 120^{T}$ against R. solanacearum}

Strain $\mathrm{LD} 120^{\mathrm{T}}$ showed antagonistic potential against $R$. solanacearum by forming characteristic clear zone (diameter of $12.3 \mathrm{~mm}$ ), inhibiting the growth of the pathogen in vitro in antagonism assay (Figure 4A). To determine whether the isolate had biocontrol potential against $R$. solanacearum in planta, we evaluated the efficacy of the isolate for control of $R$. solanacearum on tomato seedlings. After 15 days of the inoculation of $R$. solanacearum, some visual wilt symptoms of tomato seedlings were exhibited in both CKR and the treatment groups. In comparison with CKR, the application of strain LD120 significantly reduced the disease severity of bacterial wilt on tomato seedlings (Figure 4B). The spore concentration of $10^{7} \mathrm{CFU} / \mathrm{g}$ in soil showed the highest biocontrol efficacy (63.6\%) (Figure 4C). This result suggest that strain $\mathrm{LD} 120^{\mathrm{T}}$ has the potential to be developed as a biofertilizer to prevent bacterial wilt on tomato. To mine the biosynthetic potential of strain $\mathrm{LD} 120^{\mathrm{T}}$ associated with antibacterial activity, the draft genome was analyzed using antiSMASH, leading to identification of 37 putative gene clusters, among which, two gene clusters showed $75 \%$ and $93 \%$ similarities with the biosynthetic gene clusters of salinomycin and fluostatin, respectively, which have been reported to possess significant antibacterial activity $[49,50]$. However, considering the poor quality of the genome sequence, with a large number of gaps, it may not be related to the antibacterial active components identified with antibiotics and secondary metabolite analysis shell-antiSMASH. Further research is needed to identify the active products in strain LD120 $0^{\mathrm{T}}$. 

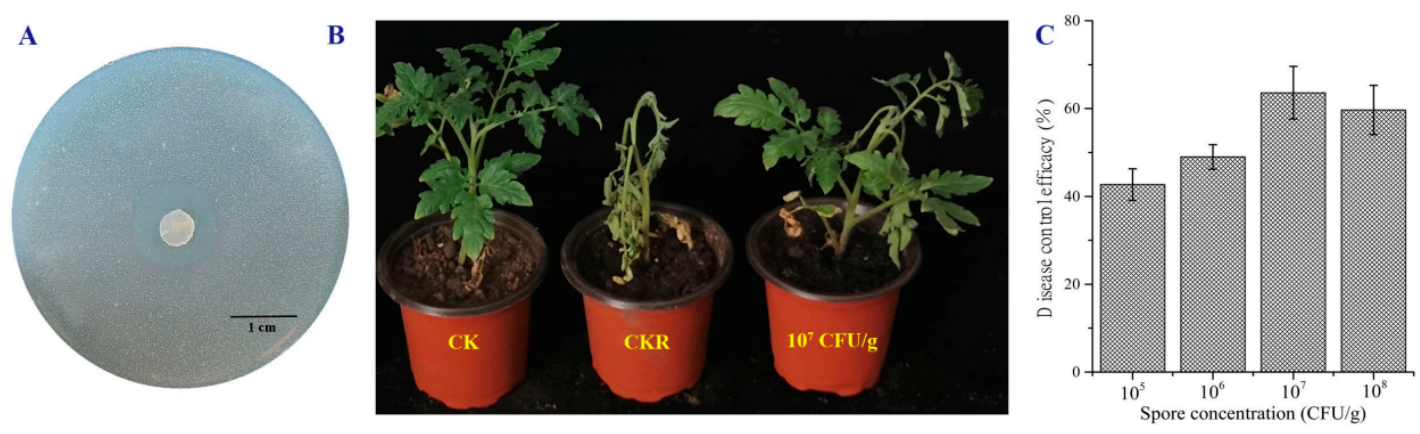

Figure 4. Antibacterial activity of strain $\mathrm{LD} 120^{\mathrm{T}}$ against $R$. solanacearum. (A) the antagonistic activity against $R$. solanacearum in the sucrose-peptone agar (SPA) plate. $(\mathbf{B}, \mathbf{C})$ biocontrol assay of inoculation with $R$. solanacearum and strain $\mathrm{LD} 120^{\mathrm{T}}$ on tomato seedlings in the greenhouse.

\section{Conclusions}

An endophytic actinomycete, strain LD120 ${ }^{\mathrm{T}}$, was isolated from moss (P. sphaericum (Ludw) Fuernr). Morphological and chemotaxonomic features, together with phylogenetic analysis, suggested that strain LD $120^{\mathrm{T}}$ belonged to the genus Streptomyces. Phenotypic characteristics combined with ANI and $\mathrm{dDDH}$ values clearly revealed that strain $\mathrm{LD} 120^{\mathrm{T}}$ was differentiated from its closely related strains. Based on the polyphasic taxonomic analysis, it is suggested that strain $\mathrm{LD} 120^{\mathrm{T}}$ represents a novel species of the genus Streptomyces, for which the name S. physcomitrii sp. nov. is proposed. The type strain was $\mathrm{LD} 120^{\mathrm{T}}\left(=\right.$ CCTCC AA $\left.2018049^{\mathrm{T}}=\mathrm{DSM} 110638^{\mathrm{T}}\right)$. In addition, the antibacterial activity of strain $\mathrm{LD} 120^{\mathrm{T}}$ against $R$. solanacearum in vitro and in vivo was assessed, suggesting that it has the potential as a biocontrol agent for controlling bacterial wilt on tomato.

Supplementary Materials: The following are available online at http://www.mdpi.com/2076-2607/8/12/2025/s1, Figure S1: Maximum-likelihood tree showing the phylogenetic position of strain $\mathrm{LD} 120^{\mathrm{T}}$ and related taxa based on 16S rRNA gene sequences; Figure S2: Maximum-likelihood tree based on MLSA analysis of the concatenated partial sequences $(2481 \mathrm{bp})$ from five housekeeping genes $(\operatorname{atp} D, g y r B, r e c A, r p o B$ and $\operatorname{trp} B)$ of strain LD120 ${ }^{\mathrm{T}}$ and related taxa; Figure S3: Whole-genome sequence tree generated with TYGS for strain LD120 ${ }^{\mathrm{T}}$ and validly published species of the genus Streptomyces.; Figure S4: Cultural characteristics of strains observed on ISP 1-7, CA, NA and MBA media at $28^{\circ} \mathrm{C}$ for 14 days; Figure S5: The phospholipids of strain LD120 ${ }^{\mathrm{T}}$; Table S1: GenBank accession numbers of the sequences for the Streptomyces sequences used; Table S2: MLSA distance values for selected strains in this study; Table S3: Cultural characteristics of strain LD120 ${ }^{\mathrm{T}}$, S. azureus NRRL B- $2655^{\mathrm{T}}$ and S. anandii NRRL B- $3590^{\mathrm{T}}$.

Author Contributions: X.Z., C.G. and C.P. performed the experiments; Z.W. and J.Z. analyzed the data; X.Z. and C.G. wrote the paper; C.L. designed the experiments; C.L. and Y.S. reviewed the manuscript. All authors have read and agreed to the published version of the manuscript.

Funding: This work was supported by the Postdoctoral Start-up Fund of Heilongjiang Province (LBH-Q19011 and LBH-Q19082).

Acknowledgments: We thank Aharon Oren for his valuable help with naming the species. We would also like to acknowledge Bo Liu, from the Agricultural Microbiology Research Center, Institute of Agricultural Biological Resources, Fujian Academy of Agricultural Sciences, for providing R. solanacearum strain FJAT-91.

Conflicts of Interest: The authors declare no conflict of interest.

\section{References}

1. Mansfield, J.; Genin, S.; Magori, S.; Citovsky, V.; Sriariyanum, M.; Ronald, P.; Dow, M.; Verdier, V.; Beer, S.V.; Machado, M.A.; et al. Top 10 plant pathogenic bacteria in molecular plant pathology. Mol. Plant Pathol. 2012, 13, 614-629. [CrossRef]

2. Barika, S.; Reddy, A.C.; Ponnam, N.; Kumari, M.; Acharya, G.C.; Lakshmana Reddy, D.C.L.; Petikam, S.; Gs, S. Breeding for bacterial wilt resistance in eggplant (Solanum melongena L.): Progress and prospects. Crop. Prot. 2020, 137, 105270. [CrossRef] 
3. Smith, E.F. A Bacterial Disease of the Tomato, Eggplant and Irish Potato (Bacillus solanacearum nov. sp.); Division of Vegetable Physiology and Pathology Bulletin No 12; United States Department of Agriculture: Washington, DC, USA, 1896.

4. Wicker, E.; Grassart, L.; Coranson-Beaudu, R.; Mian, D.; Guilbaud, C.; Fegan, M. Ralstonia solanacearum strains from Martinique (French West Indies) exhibiting a new pathogenic potential. Appl. Environ. Microibiol. 2007, 71, 6790-6801. [CrossRef] [PubMed]

5. Vu, T.T.; Kim, J.C.; Choi, Y.H.; Choi, G.J.; Jang, K.S.; Choi, T.H.; Yoon, T.M.; Lee, S.W. Effect of gallotannins derived from Sedum takesimense on tomato bacterial wilt. Plant Dis. 2013, 97, 1593-1598. [CrossRef] [PubMed]

6. Namisy, A.; Chen, J.; Prohen, J.; Metwally, E.; Elmahrouk, M.; Rakha, M. Screening of cultivated eggplant and wild relatives for resistance to bacterial wilt (Ralstonia solanacearum). Agriculture 2019, 9, 157. [CrossRef]

7. Wisniewski, M.; Droby, S.; Norelli, J.; Liu, J.; Schena, L. Alternative management technologies for postharvest disease control: The journey from simplicity to complexity. Postharvest Biol. Technol. 2016, 122, 3-10. [CrossRef]

8. $\quad$ Ling, L.; Han, X.; Li, X.; Zhang, X.; Wang, H.; Zhang, L.; Cao, P.; Wu, Y.; Wang, X.; Zhao, J.; et al. A Streptomyces sp. NEAU-HV9: Isolation, identification, and potential as a biocontrol agent against Ralstonia solanacearum of tomato plants. Microorganisms 2020, 8, 351. [CrossRef] [PubMed]

9. Agarwal, H.; Dowarah, B.; Baruah, P.M.; Bordoloi, K.S.; Krishnatreya, D.B.; Agarwala, N. Endophytes from Gnetum gnemon L. can protect seedlings against the infection of phytopathogenic bacterium Ralstonia solanacearum as well as promote plant growth in tomato. Microbiol. Res. 2020, 238, 126503. [CrossRef]

10. Alamer, I.S.A.; Tomah, A.A.; Li, B.; Zhang, J.Z. Isolation, identification and characterization of rhizobacteria strains for biological control of bacterial wilt (Ralstonia solanacearum) of eggplant in China. Agriculture 2020, 10, 37. [CrossRef]

11. Ciampi-Panno, L.; Fernandez, C.; Bustamante, P.; Andrade, N.; Ojeda, S.; Conteras, A. Biological control of bacterial wilt of potatoes caused by Pseudomonas solanacearum. Am. Potato J. 1989, 66, 315-332. [CrossRef]

12. Golinska, P.; Wypij, M.; Agarkar, G.; Rathod, D.; Dahm, H.; Rai, M. Endophytic actinobacteria of medicinal plants: Diversity and bioactivity. Antonie Van Leeuwenhoek 2015, 108, 267-289. [CrossRef] [PubMed]

13. Mingma, R.; Pathom-aree, W.; Trakulnaleamsai, S.; Thamchaipenet, A.; Duangmal, K. Isolation of rhizospheric and roots endophytic actinomycetes from Leguminosae plant and their activities to inhibit soybean pathogen, Xanthomonas campestris pv. glycine. World J. Microbiol. Biotechnol. 2014, 30, 271-280. [CrossRef] [PubMed]

14. Liu, C.X.; Zhuang, X.X.; Yu, Z.Y.; Wang, Z.Y.; Wang, Y.J.; Guo, X.W.; Xiang, W.S.; Huang, S.X. Community structures and antifungal activity of root-associated endophytic actinobacteria of healthy and diseased soybean. Microorganisms 2019, 7, 243. [CrossRef] [PubMed]

15. Cao, P.; Li, C.X.; Wang, H.; Yu, Z.Y.; Xu, X.; Wang, X.J.; Zhao, J.W.; Xiang, W.S. Community structures and antifungal activity of root-associated endophytic actinobacteria in healthy and diseased cucumber plants and Streptomyces sp. HAAG3-15 as a promising biocontrol agent. Microorganisms 2020, 8, 236. [CrossRef]

16. Liotti, R.G.; Figueiredo, M.I.d.S.; Soares, M.A. Streptomyces griseocarneus R132 controls phytopathogens and promotes growth of pepper (Capsicum annuum). Biol. Control. 2019, 138, 104065. [CrossRef]

17. Liu, D.; Yan, R.; Fu, Y.; Wang, X.; Zhang, J.; Xiang, W. Antifungal, plant growth-promoting, and genomic properties of an endophytic actinobacterium Streptomyces sp. NEAU-S7GS2. Front. Microbiol. 2019, 10, 2077. [CrossRef]

18. Qin, S.; Li, J.; Chen, H.H.; Zhao, G.Z.; Zhu, W.Y.; Jiang, C.L.; Xu, L.H.; Li, W.J. Isolation, diversity, and antimicrobial activity of rare actinobacteria from medicinal plants of tropical rain forests in Xishuangbanna, China. Appl. Environ. Microbiol. 2009, 75, 6176-6186. [CrossRef]

19. Shirling, E.B.; Gottlieb, D. Methods for characterization of Streptomyces species. Int. J. Syst. Bacteriol. 1966, 16, 313-340. [CrossRef]

20. Jin, L.Y.; Zhao, Y.; Song, W.; Duan, L.P.; Jiang, S.W.; Wang, X.J.; Zhao, J.W.; Xiang, W.S. Streptomyces inhibens sp. nov., a novel actinomycete isolated from rhizosphere soil of wheat (Triticum aestivum L.). Int. J. Syst. Evol. Microbiol 2019, 69, 688-695. [CrossRef]

21. Waksman, S.A. The Actinomycetes. In A Summary of Current Knowledge; Ronald Press: New York, NY, USA, 1967.

22. Jones, K.L. Fresh isolates of actinomycetes in which the presence of sporogenous aerial mycelia is a fluctuating characteristic. J. Bacteriol. 1949, 57, 141-145. [CrossRef] 
23. Zhao, J.W.; Han, L.Y.; Yu, M.Y.; Cao, P.; Li, D.M.; Guo, X.W.; Liu, Y.Q.; Wang, X.J.; Xiang, W.S. Characterization of Streptomyces sporangiiformans sp. nov., a novel soil actinomycete with antibacterial activity against Ralstonia solanacearum. Microorganisms 2019, 7, 360. [CrossRef] [PubMed]

24. Yan, Y.; Yang, J.; Yu, Z.; Yu, M.; Ma, Y.T.; Wang, L.; Su, C.; Luo, J.; Horsman, G.P.; Huang, S.X. Non-enzymatic pyridine ring formation in the biosynthesis of the rubrolone tropolone alkaloids. Nat. Commun. 2016, 7, 13083. [CrossRef] [PubMed]

25. Zhuang, X.X.; Wang, Z.Y.; Peng, C.H.; Su, C.; Gao, C.T.; Wang, Y.J.; Huang, S.X.; Liu, C.X. Characterization of Streptomyces piniterrae sp. nov. and identification of the putative gene cluster encoding the biosynthesis of heliquinomycins. Microorganisms 2020, 8, 495. [CrossRef] [PubMed]

26. Yu, Z.Y.; Han, C.Y.; Yu, B.; Zhao, J.W.; Yan, Y.J.; Huang, S.X.; Liu, C.X.; Xiang, W.S. Taxonomic characterization, and secondary metabolite analysis of Streptomyces triticiradicis sp. nov.: A novel actinomycete with antifungal activity. Microorganisms 2020, 8, 77. [CrossRef]

27. Jia, F.Y.; Liu, C.X.; Wang, X.J.; Zhao, J.W.; Liu, Q.F.; Zhang, J.; Gao, R.X.; Xiang, W.S. Wangella harbinensis gen. nov., sp. nov., a new member of the family Micromonosporaceae. Antonie Van Leeuwenhoek 2013, 103, 399-408. [CrossRef]

28. McKerrow, J.; Vagg, S.; McKinney, T.; Seviour, E.M.; Maszenan, A.M.; Brooks, P.; Sevious, R.J. A simple HPLC method for analyzing diaminopimelic acid diastereomers in cell walls of Gram-positive bacteria. Lett. Appl. Microbiol. 2000, 30, 178-182. [CrossRef]

29. Lechevalier, M.P.; Lechevalier, H.A. The Chemotaxonomy of Actinomycetes. In Actinomycete Taxonomy; Dietz, A., Thayer, D.W., Eds.; Special Publication for Society of Industrial Microbiology: Arlington, TX, USA, 1980; pp. 227-291.

30. Minnikin, D.E.; O’Donnell, A.G.; Goodfellow, M.; Alderson, G.; Athalye, M.; Schaal, A.; Parlett, J.H. An integrated procedure for the extraction of bacterial isoprenoid quinones and polar lipids. J. Microbiol. Methods 1984, 2, 233-241. [CrossRef]

31. Collins, M.D. Isoprenoid Quinone Analyses in Bacterial Classification and Identification. In Chemical Methods in Bacterial Systematics; Goodfellow, M., Minnikin, D.E., Eds.; Academic Press: Cambridge, MA, USA, 1985; pp. 267-284.

32. Zhuang, X.X.; Peng, C.H.; Wang, Z.Y.; Zhao, J.W.; Shen, Y.; Liu, C.X.; Xiang, W.S. Actinomadura physcomitrii sp. nov., a novel actinomycete isolated from moss [Physcomitrium sphaericum (Ludw) Fuernr]. Antonie Van Leeuwenhoek 2020, 113, 677-685. [CrossRef]

33. Wang, Z.Y.; Yu, Z.Y.; Zhao, J.W.; Zhuang, X.X.; Cao, P.; Guo, X.W.; Liu, C.X.; Xiang, W.S. Community composition, antifungal activity and chemical analyses of ant-derived actinobacteria. Front. Microbiol. 2020, 11, 201. [CrossRef]

34. Yoon, S.H.; Ha, S.M.; Kwon, S.; Lim, J.; Kim, Y.; Seo, H.; Chun, J. Introducing EzBioCloud: A taxonomically united database of 16S rRNA and whole genome assemblies. Int. J. Syst. Evol. Microbiol. 2017, 67, 1613-1617. [CrossRef]

35. Saitou, N.; Nei, M. The neighbor-joining method: A new method for reconstructing phylogenetic trees. Mol. Biol. Evol. 1987, 4, 406-425. [PubMed]

36. Felsenstein, J. Evolutionary trees from DNA sequences: A maximum likelihood approach. J. Mol. Evol. 1981, 17, 368-376. [CrossRef] [PubMed]

37. Kumar, S.; Stecher, G.; Tamura, K. Mega7: Molecular evolutionary genetics analysis version 7.0 for bigger datasets. Mol. Biol. Evol. 2016, 33, 1870-1874. [CrossRef]

38. Felsenstein, J. Confidence limits on phylogenies: An approach using the bootstrap. Evolution 1985, 39, 83-791. [CrossRef] [PubMed]

39. Kimura, M. A simple method for estimating evolutionary rates of base substitutions through comparative studies of nucleotide sequences. J. Mol. Evol. 1980, 16, 111-120. [CrossRef] [PubMed]

40. Nikodinovic, J.; Barrow, K.D.; Chuck, J.A. High yield preparation of genomic DNA from Streptomyces. Biotechniques 2003, 35, 932-934. [CrossRef] [PubMed]

41. Coil, D.; Jospin, G.; Darling, A.E. A5-miseq: An updated pipeline to assemble microbial genomes from Illumina MiSeq data. Bioinformatics 2015, 31, 587-589. [CrossRef]

42. Meier-Kolthoff, J.P.; Auch, A.F.; Klenk, H.P.; Goker, M. Genome sequence-based species delimitation with confidence intervals and improved distance functions. BMC Bioinform. 2013, 14, 60. [CrossRef] 
43. Yoon, S.H.; Ha, S.M.; Lim, J.; Kwon, S.; Chun, J. A large scale evaluation of algorithms to calculate average nucleotide identity. Antonie Van Leeuwenhoek 2017, 110, 1281-1286. [CrossRef]

44. Blin, K.; Wolf, T.; Chevrette, M.G.; Lu, X.; Schwalen, C.J.; Kautsar, S.A.; Duran, H.G.S.; de los Santos, E.L.C.; Kim, H.U.; Nave, M.; et al. Antismash 4.0-improvements in chemistry prediction and gene cluster boundary identification. Nucleic Acids Res. 2017, 45, W36-W41. [CrossRef]

45. Wayne, L.G.; Brenner, D.J.; Colwell, R.R.; Grimont, P.A.D.; Kandler, O. Report of the ad hoc committee on reconciliation of approaches to bacterial systematics. Int. J. Syst. Bacteriol. 1987, 37, 463-464. [CrossRef]

46. Richter, M.; Rosselló-Móra, R. Shifting the genomic gold standard for the prokaryotic species definition. Proc. Natl. Acad. Sci. USA 2009, 106, 19126-19131. [CrossRef] [PubMed]

47. Rong, X.; Huang, Y. Taxonomic evaluation of the Streptomyces hygroscopicus clade using multilocus sequence analysis and DNA-DNA hybridization, validating the MLSA scheme for systematics of the whole genus. Syst. Appl. Microbiol. 2012, 35, 7-18. [CrossRef] [PubMed]

48. Kämpfer, P.; Genus, I. Streptomyces Waksman and Henrici 1943, 339 AL. In Bergey's Manual of Systematic Bacteriology, 2nd ed.; Springer: New York, NY, USA, 2012; pp. 1679-1680.

49. Huczyński, A.; Janczak, J.; Stefańska, J.; Antoszczak, M.; Brzezinski, B. Synthesis and antimicrobial activity of amide derivatives of polyether antibiotic-salinomycin. Bioorg. Med. Chem. Lett. 2012, 22, 4697-4702. [CrossRef]

50. Yang, C.; Huang, C.; Zhang, W.; Zhu, Y.; Zhang, C. Heterologous expression of fluostatin gene cluster leads to a bioactive heterodimer. Org. Lett. 2015, 17, 5324-5327. [CrossRef]

Publisher's Note: MDPI stays neutral with regard to jurisdictional claims in published maps and institutional affiliations.

(C) 2020 by the authors. Licensee MDPI, Basel, Switzerland. This article is an open access article distributed under the terms and conditions of the Creative Commons Attribution (CC BY) license (http://creativecommons.org/licenses/by/4.0/). 